\title{
森田組東口マーケットの形成と戦災復興土地区画整理事業からみる 池袋駅東口の戦災復興過程
}

\author{
THE WAR-DAMAGE-RECOVERY PROCESS OF THE IKEBUKURO STATION EAST GATE, \\ WITH RESPECT TO THE FORMATION OF THE MORITA-GUMI EAST GATE MARKET \\ AND THE WAR-DAMAGE-RECOVERY LAND READJUSTMENT PROGRAMS
}

\author{
石 榑 督 和* \\ Masakazu ISHIGURE
}

\begin{abstract}
This study takes as its subject the east gate of Ikebukuro station. Having verified the prewar organization of the city and plans for the square in front of the station, the study reveals the scope of the transport evacuation spaces, the state of war damage, the formation of postwar markets, street stand organization programs, and the reorganization of markets following war-damage-recovery land readjustment programs, and accordingly the subsequent process of new market construction. Particular attention is paid to the fact that Nezuyama, a grove of mixed trees that had not been developed since before the war, was located adjacent to Ikebukuro station. The war-damage-recovery land readjustment program for the Ikebukuro station east gate progressed most rapidly even within the city; one of the background factors here was the existence of Nezuyama.
\end{abstract}

Keywords: Ikebukuro, black market, "M arket", land readjustment for war-damage reconstruction, street stall keeper, stall 池袋，闇市，マーケット，戦災復興土地区画整理，テキ屋，露店

1.はじめに

\section{(1) 本稿の課題}

現在の東京の都市構造は鉄道ネットワークに支えられ、とくに山 手線の主要駅を中心としたエリアが高度に市街地化している。新宿 駅、池袋駅、渋谷駅周辺は戦前から新興の盛り場として発展しつつ あったが、とくに「敗戦直後からヤミ市の成立とその発展を契機に、 現在の副都心と呼ばれているような機能を備えるに至った」 ${ }^{1)}$ とい われ、駅を中心とした都市形成が戦後に本格化した。こうしたエリ アは、近世までの市街地のフリンジやそのすぐ外側に位置し、近現 代の東京の形成過程において劇的な変化を経験し、都市構造におい ても重要な位置を占めてきたが、形成過程に関する研究蓄積がそし い。同エリアは、戦前期の私鉄敷設による駅のターミナル化と東京 の西側の郊外化を背景とする都市化、戦中期の疎開空地による土地 所有構造の劇的変化と建物の除去、戦後復興期の闇市を起源とする マーケットによる土地の不法占拠、区画整理による市街地の再編、 高度経済成長を背景とする建物の建替えと高度化など都市景観の劇 的な変化を経験してきた場所であり、形成過程を解明するには、こ うした状況を段階的に把握し、それらの関係性を明らかにする必要 がある。

筆者はすでに新宿駅東口駅前の街区を対象に、東京の巨大ターミ ナル近傍の形成過程の一端を明らかにしている ${ }^{2)}$ 。新宿駅東口駅前 の街区では、戦後復興期に建設された闇市を起源とするマーケット
は、土地所有権を持たないにも関わらず十数年もの間駅前を占有し 続け、1960 年頃に戦災復興土地区画整理事業によって整理された。 その後、新宿駅東口を対象とする東京都市計画第 9-2 工区復興土地 区画整理事業は、1970 年 3 月 31 日に換地処分されている。

本稿は池袋駅東口を対象とし、戦前の市街地を確認したうえで、 交通疎開空地の範囲、戦災の状況、戦後のマーケットの形成、戦災 復興土地区画整理事業によるマーケットの整理・移転と露店整理事 業の過程を明らかにすることを目的としている。新宿駅東口を対象 とした戦災復興土地区画整理事業が換地処分までに終戦から 25 年 を要したのに対し、池袋駅東口を対象とした戦災復興土地区画整理 事業は 1960 年 10 月 31 日に換地処分されている。両者には 10 年も の差があるが、本論を先取りして言えば、その背景には根津山と呼 ばれた一主体が所有した未開発の土地が駅近傍に存在したことがあ る。戦後復興期、区画整理を進める際にこの根津山が分譲されたこ とで、多くの新規地主が生まれ、整理対象となったマーケットの営 業者に移転先を与え、戦災復興土地区画整理事業用地内に新たな マーケットが複数建設された。これが戦前までに駅周辺の市街地化 が進み空地が残されていなかった新宿とは異なる、池袋駅東口の戦 災復興を可能にした。

\section{(2) 本稿に関係する既往研究}

池袋の闇市については星野朗・松平誠による研究がある ${ }^{3)}$ 。星野・ 松平の研究は、星野が戦後復興期に行った現地調査および戦後復興

\footnotetext{
$*$ 東京理科大学工学部建築学科 助教 $\cdot$ 博士 (工学)
} Assist. Prof., Dept. of Architecture, Faculty of Engineering, Tokyo Univ. of Science, Dr. Eng. 
期に森田組東ロマーケットで営業を行っていた方への聞取り調査 （1983 年）によって、戦後復興期の池袋駅周辺の闇市に焦点を当て 空間的に復原している。そのため、闇市が建設された場所の戦前の 状況、および 1950 年以降の変化については論じていない。これに 対し、初田香成は東京の闇市を戦前戦後を通じた時間軸のなかで捉 え、戦前の小売市場との関係や闇市が変容していく姿に注目した ${ }^{4)}$ 。 闇市に対象を絞ってその変容を明らかにした初田に対して、あるエ リアの形成過程を明らかにするうえで闇市の形成と変容に焦点を当 てた研究に、神戸を対象とした村上しほりの研究がある ${ }^{5)}$ 。村上は 戦前の市街地の性質と戦後の闇市の形成を関連付け、マーケットの 変容の過程を緻密に明らかにした。村上は占領期の仮設的な市街地 形成に焦点を絞ったのに対し、本稿は闇市を起源とするマーケット の形成をみたうえで、戦災復興土地区画整理事業によって形成が進 む恒常的な都市空間において、戦後のマーケットや露店がいかに変 容しながらも持続していったのかということに注目する。

\section{（3）研究方法と資料}

本稿では都市整図社発行の火災保険特殊地図や、米軍撮影の航空 写真から市街地の状況を把握するとともに、戦災復興土地区画整理 事業による換地を復原し、また同時に法務局で公開されている旧土 地台帳や登記情報をもとに土地所有の変遷を確認し、市街地形成と の関係を分析している。戦災復興土地区画整理事業による土地の換 地については、東京都所蔵の東京都市計画第 10-1工区復興土地区 画整理事業の換地確定図と換地明細書をもとに図 5 ・6 および表 1 ・ 2 を作成した。また、こうした資料のほか、市街地形成と変容の要 因を明らかにするため、新聞や社史、都市計画の事業誌を使用して いる。

\section{2. 駅前の市街地化と戦災 終戦までの形成過程}

\section{(1) 戦前期 1938 年}

池袋駅周辺は、新宿、渋谷とともに副都心の繁華街として成長し ていくが、それは打もに戦後のことである。池袋が都市として成長

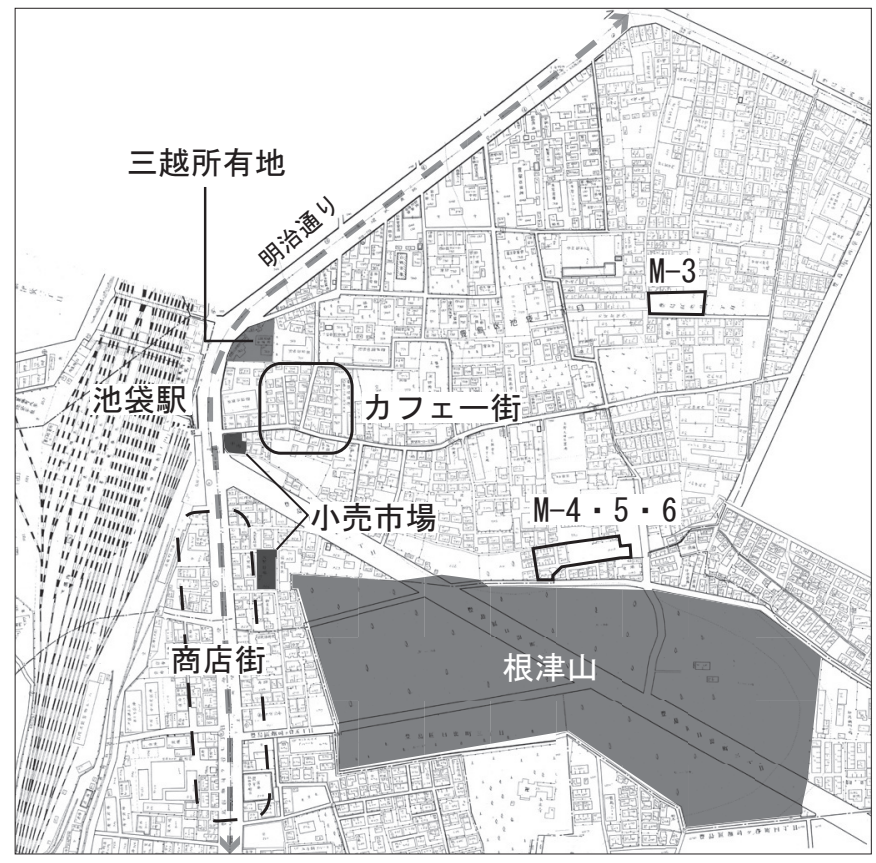

図 11938 年の対象地区の火災保険特殊地図（都市整図社発行）
し始めるのは武蔵野鉄道、東上鉄道など私鉄が開業してからであ る。豊島区域の人口は第一次世界大戦期に年々増加し、1918 年に は約 8 万人、1920 年には 10 万人を超えて、畑と雑木林が広がる田 園から東京の郊外住宅地一と変化していく。1932 年、巣鴨町・西 巣鴨町・長崎町・高田町が東京市へ編入し、4 町の区域をもって豊 島区が誕生する。このころ、交通拠点としての池袋駅の乗降客数は 増加していった。

この時期、東京の他の私鉄のターミナルには、従来からの百貨店 や、私鉄資本による新しい百貨店が進出しつつあった。池袋駅東口 でも 1935 年 11 月に、吳服店系老舗百貨店の白木屋と京浜電気鉄道 が共同で設立した京浜百貨店が「菊屋デパート」をオープンさせ た。これを武蔵野鉄道が買収し、武蔵野デパートと改称してオープ ンしたのが 1940 年 3 月であった。一方で、戦後に対象地区の駅前 広場に面して店舗を建設する三越も、戦前に池袋駅東口に進出して いる。三越は、1928 年に駅前に分店を設置するために土地 723 坪 を取得している ${ }^{6)}$ (図 1)。

図 1 は 1938 年の火災保険特殊地図である。商店街が明治通り沿 いに展開していることが確認できる。また、こうした表通りの小売 店に対し、駅前の路地を入るとカフェーが並んでいる。そして、駅 前にはふたつの市場があった。繁華街と呼べるのは駅前にかぎられ ていた。とくに駅南東には、財団法人根津育英会（財団法人根津育 英会は東武鉄道社長の根津嘉一郎が設立した奨学育成財団）の所有 地である根津山と呼ばれた広大な林が未開発のまま残っていた。こ こが終戦まで、地目上「畑」として残っていたことが、池袋駅東口 の戦災復興に大きく影響することとなる。

\section{（2）建物疎開と戦災 $1944-45$ 年}

池袋駅東口では疎開事業の第 3 次指定 (1944 年 4 月 17 日) によっ て 5300 坪が交通疎開空地に指定され、駅前の建物が除去された ${ }^{7)}$ 。 図 2 は対象地区の疎開空地を示した『豊島区建物疎開地区図』であ る。この図面では疎開空地が 3 種に塗り分けられている。幅員の広 い「疎開空地帯」が緑、あるポイント周辺を面的に建物疎開する「疎 開空地」が黄色、幅員の狭い帯状の「疎開小空地」が赤である。対

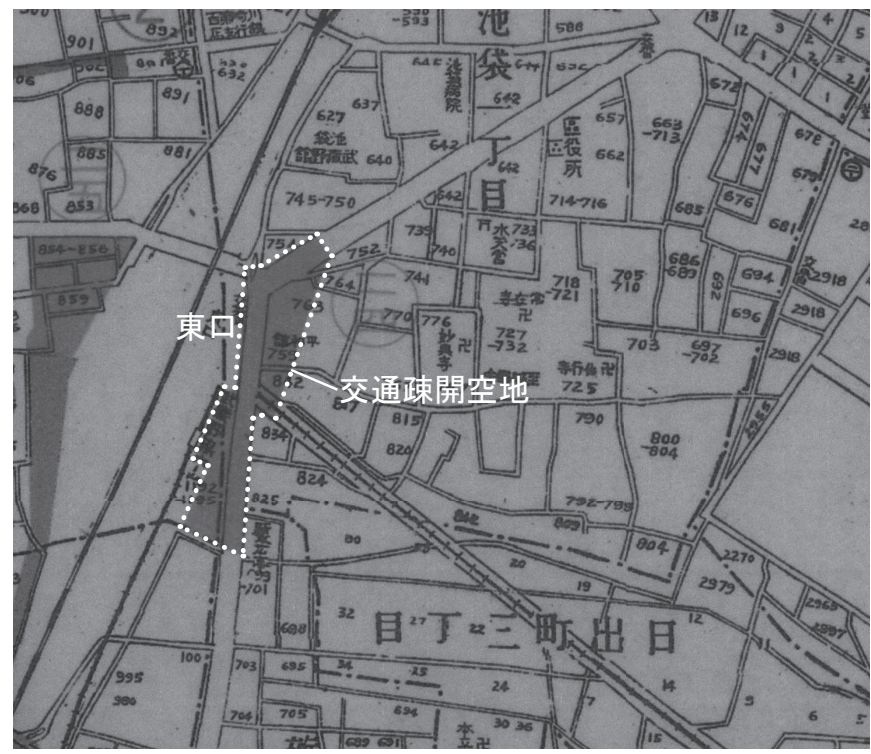

図 2 『豊島区建物疎開地区図』東京都防衛局建物疎開課、1944 年 5 月 (豊島区郷土資料館蔵) 


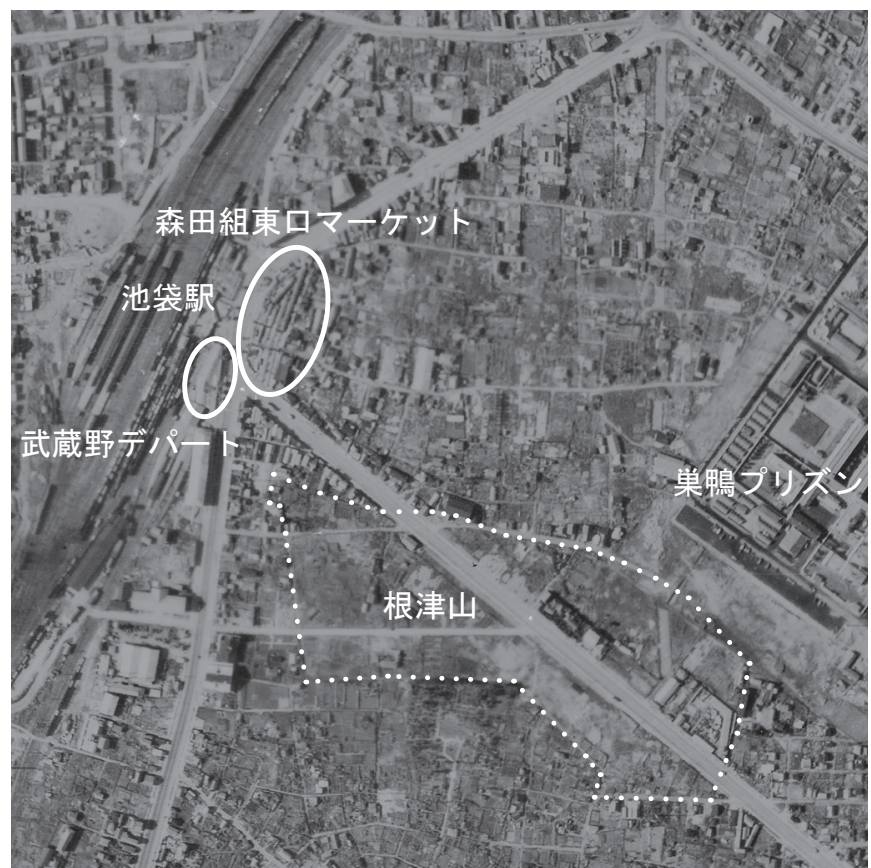

写真 11947 年 8 月 8 日米軍撮影「USA-M390-34」(国土地理院蔵)

象地区の交通疎開空地は「疎開空地」に該当し、図 2 の原本では黄 色く塗られている。疎開空地の「土地は所有者の申出に依り都で買 うか借りること」 ${ }^{8)}$ になっていた。池袋駅東口駅前の交通疎開空地 となった土地の旧土地台帳は管轄の法務局出張所に保管されておら ず、散逸してしまっているため、この時期にどの範囲が東京都によっ て買収されたのかは不明であるが、交通疎開空地に指定された範囲 はこの時期から戦後 1947 年頃まで東京都の管理地（都有地もしく は都が借地した土地）であった。

対象地区は 1945 年 4 月 13 日に空襲を受け焼き尽くされた。池袋 駅東口方面には大規模な耐火建築はなく、焼け野原が広がった。

\section{3. 森田組東ロマーケットと露店の形成 $1945-47$ 年}

\section{（1）終戦直後の池袋駅東口に関する資料}

空襲を受けた池袋駅東口の終戦から 1947 年までの再生の過程を 明らかにする資料は 3 つ存在する。

ひとつは 1947 年 8 月 8 日に米軍によって撮影された航空写真 「USA-M390-34」である（写真 1)。ふたつ目は、当時東京高等師範 学校文科 4 部 2 年に在学中であった星野朗が、1947 年 2 月〜 5 月 の池袋駅周辺の連鎖商店街（マーケット）を対象として、その実態 を調查しまとめた記録「池袋駅を中心とする連鎖商店街について」 ${ }^{9)}$ である。この記録には星野が調査した、全 13 カ所のマーケットの 建設時期、規模、店舗数、業種などの情報がまとめられており、当 時の池袋駅周辺のマーケットの状況を示す重要な資料である。3 目は、松平誠が主となって 1983 年 3 月〜 10 月に実施した聞き取り 調査の記録「池袋『や夕市』の実態一第 2 次世界大戦後の戦災復興 マーケット一」 ${ }^{10)}$ である。この記録は、当時の営業者に聞き取り 調查を行いながら、戦後復興期のマーケットの店舗を図面に起こし 店舗内の造作物までも復原したものである。本章では、ひとつ目の 航空写真「USA-M390-34」（写真 1）と、星野の「池袋駅を中心とす る連鎖商店街について」をおもな資料として用い、補足的に松平に よる「池袋『やみ市』の実態一第 2 次世界大戦後の戦災復興マーケッ

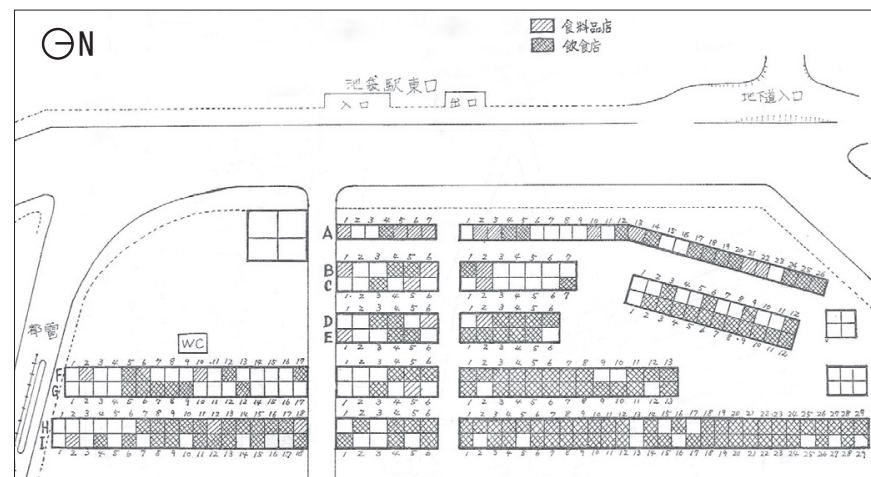

図 3 森田組東ロマーケットの配置図

（出典：星野朗「池袋駅を中心とする連鎖商店街について」『応用社 会学研究』 25 号、1984 年、119-142 頁)

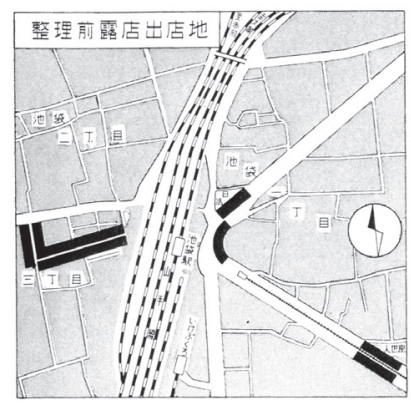

図 41950 年頃の池袋駅周辺の露店の分布（出典 : 東京都臨時露店 対策部『露店』1952 年)

ト一」を参照することで、1947 年の池袋駅東口を復原する。

（2） 1947 年の池袋駅東口

まず、写真 1 から 1947 年 8 月 8 日当時の池袋駅東口を確認したい。 戦中期に交通疎開空地として建物踈開が行われていた駅前の街区と 西武鉄道（旧武蔵野鉄道）の土地には、建物が再建されている。駅 前の街区の交通疎開空地跡地には、建物疎開以前の街区の範囲を埋 めるようにマーケットが建設されている。これは都内でも最初期に 建設された森田組東ロマーケットである。

西武鉄道の所有地で、戦前に武蔵野デパート（旧菊屋デパート） が建っていた場所には、戦後も武蔵野デパートが再建されている。

さらにこれらの周辺に目を向けると、街区のガワの部分にのみ建 物が再建されていることがわかる。とくに駅を中心にした大通り沿 いに建物が再建されているが、そこから一歩街区内部一踏み入れる と焼け跡が広がっており、一部の宅地は農地に戻っている。終戦か ら 2 年が経過した時期であるが、新宿や渋谷と比較すると建物の再 建が進んでいない。

池袋駅東口では、終戦から戦災復興土地区画整理事業が行われ るまでの時期に描かれた火災保険特殊地図が存在しないため、ど ういった建物が戦災後に再建されていたか詳しくはわからないが、 マーケットについては星野朗による詳細な記録が存在するため、星 野の記録から森田組東口マーケットについて見ていくことにした い。

\section{（3）森田組東ロマーケットの建設}

森田組東ロマーケットは、テキ屋の森田信一を親分とする森田組 によって建設された、池袋駅周辺で最初の木造長屋形式のマーケッ トであった ${ }^{11)}$ 。1946 年 2 月中旬に建設が始まり、「明るい連鎖市場 $(\mathrm{J} \cdot \mathrm{V} \cdot \mathrm{C}) 」 を$ 看板に掲げて翌 3 月にオープンした。建設段階では 
「一坪と一坪半ととりまぜ八棟二百五十戸の店が建つ豫定だが、第 一次として百三十二戸、残りの百十八戸は二次、三次工事でそれぞ れ」 ${ }^{12)}$ を建設し、2 月一杯に竣工した。1946 年 2 月に第一次の募集 を行ったところ、400人の申込があり東京露店商同業組合池袋支部 で「露店商人の範となる心゙き人を基準に」選定したという。申込金 は1000 円、あとは店を開いた日だけ雑費として 5 円取ることになっ ていた。

星野朗が調查した 1947 年 $2 \sim 5$ 月ごろには、森田組東ロマーケッ 卜は 600 ～ 700 坪の土地を占め、建坪は 346 坪で 257 軒の店舗が並 んでいた ${ }^{13)}$ 。建物の配置は図 3 の通りである。星野がふった記号 で言えば、マーケットにはA から I までの、全 9 列の店舗がある。 駅に一番近い $\mathrm{A}$ 列は、明治通りに向かって店を開く長屋が並んで おり、この列より東は、B 列と C 列、 D 列と $\mathrm{E}$ 列、 $\mathrm{F}$ 列と $\mathrm{G}$ 列、 $\mathrm{H}$ 列 と I 列というように背中合わせのコマが東西に開きながら並んでい る。こうした B 列から I 列までの建物は切妻屋根で、平入の棟割り 長屋となっている。マーケットの 1 区画の規模は、A列および $\mathrm{H} ・ \mathrm{I}$ 列でいずれも間口 1 間奥行 1 間で、その他の列では 1 区画間口 1 間 奥行 1 間ないし間口 1 間半奥行 1 間であった。

2 章で夕たとおり、この土地は 1944 年に交通疎開空地に指定さ れ、所有者の申し出により都で買い取るか、借りていた土地である。 森田組東口マーケットが建設された土地は、当時東京都の管轄下に あった。このマーケット建設に都の許可があったかは明らかでない が、建設には当時貴族院議員であった松本学も関わっていることか ら、許可なく建設を進めたわけではなく、なんらかの折衝があった ものと推察される ${ }^{14)}$

このような権利関係が 1947 年にずれることとなる。すなわち地 権者が都から、民間人へと変化したということである。交通踈開空 地として都有地もしくは都の管理地となっていた土地は、1947 年 ころに戦前の権利者へと土地に関わる権利が戻されたため ${ }^{15)}$ 、そ れ以降は森田組東ロマーケットが占有する土地は民有地になったと 推察される ${ }^{16)}$ 。

後述するが、森田組東ロマーケットは戦災復興土地区画整理事業 に際して、都から金銭的補償や移転場所の斡旋を受けて立ち退くこ ととなる。つまり、公式な土地に関わる権利（所有権・借地権）を 持たなかったため、戦災復興土地区画整理事業に際しては換地が与 えられることがなかったのである。戦後、各地の駅前に建設された 闇市を起源とするマーケットの整理は、こうした理由から難航し た。

\section{（4）池袋駅東口の露店}

終戦直後から自然発生した露店も継続的に路上に並んでいた。図 4 は池袋周辺の露店の分布を示している。この図からは駅前の森田 組東口マーケット周辺以外では、日活や人生座などの映画館周辺に 露店が並んでいたことがわかる。これは、駅前以外はあまり商店街 の復興が進んでおらず、人が集まる場所は映画館にかぎられていた ことを示している。

\section{4. 戦災復興土地区画整理事業による根津山の分譲とマーケットの 移転・整理 $1948-53$ 年}

1948 年から 1953 年の間、戦災復興土地区画整理事業によって森 田組東ロマーケットが整理されるとともに、一部の営業者はまと
まってマーケットを新設したり、集団移転をしている。また露店整 理事業によっても、新たにマーケットが建設された。これらのマー ケットはすべて池袋駅東口を対象とした戦災復興土地区画整理事業 第 10 - 1 工区の範囲内に建設されていた。池袋駅東口のマーケット や露店が駅前の戦災復興土地区画整理事業工区内に移転場所を得ら れた背景には、根津山が戦災復興土地区画整理事業第 10-1工区内 に存在したことがある。

\section{（1）区画整理が始まるまでのマーケットの変容}

1947 年中旬、東京の各地で封建的な「組」組織が解散に追い込 まれていった。森田組も1948 年中ごろまでに解散に追い込まれ、 さらに 1948 年 7 月 29 日には、森田組東ロマーケット建設以降、営 業者から税金や家賃と称して金を巻き上げ、暴利を得ていたとして 池袋署が森田組親分の森田信一を検挙している ${ }^{17)} 。$

一方で、西武資本によって建設された武蔵野デパートは、この時 期に改築が進められた。1949 年 12 月に木造モルタル外装 2 階建て の新しい建物が完成し、ターミナルデパートとして社名を武蔵野デ パートから西武百貨店に改称し再スタートしている ${ }^{18)}$ 。新築の建 物は、西武鉄道資本によって西武鉄道の資産として建設された。同 時に、それまで貸店舗を中心とした経営であった武蔵野デパート を、直営の百貨店経営に変更した。これがターミナルデパートとし ての西武百貨店の戦後のスタートである。

\section{(2) 西武の根津山買収}

この時期、西武は百貨店事業を進めるとともに、池袋駅東口の発 展をにらんで土地の買収を進めていた。西武は、武蔵野鉄道事務所 用地に隣接する商店街の建物疎開による空地 360 坪（地主 1 名、借 地権者 28 軒）を、戦後早々に交涉を始め 1947 年 1 月に買収を完了 している。この土地は、1950 年に西武が最初の本格的な駅ビルを 建設する際に、中心的な用地となった。

西武がこの交通疎開空地に続いて買収を進めたのが根津山であっ た。根津山は約 1 万 5000 坪にもおよぶ広い土地で、池袋駅の徒歩 圈内でありながら広大な雑木林として終戦を迎えていた。西武はこ の土地に着目し、根津嘉一郎東武鉄道社長に譲渡を願い出るととも に根津育英会に直接交渉し、根津山の大部分を買収寸ることに成 功、1946 年 3 月に登記を行っている ${ }^{19)}$ 。ただし、西武が根津山の 土地買收時に具体的な開発計画を持っていたわけではなかった。

他方でこの時期、戦災復興土地区画整理の計画が進展し、1946 年 12 月には池袋駅東口（第 $10-1$ 工区）の地権者（地主・借地人） からなる土地区画整理委員会において、東京都提案の戦災復興土地 区画整理の計画が具体化しつつあった ${ }^{20)}$ 。西武鉄道は同工区の大 地主として、土地区画整理委員に名を連齐ていた ${ }^{211}$ 。戦災復興土 地区画整理事業推進のためには、駅前を占拠するマーケットの整理 が急務であった。東京都は、池袋駅東口の区画整理を迅速に進める ために、西武所有となっていた根津山の土地を都へ売却するよう願 い出た ${ }^{22)}$ 。そして、西武は「都当局立案の復興・整備計画に全面 的に協力することとし」、1949 年早々に根津山を中心とした保有地 を都に売却した ${ }^{23)}$ 。

東京都はこの土地を森田組東ロマーケットの区画整理で行き場の ない人夕、1949 年からの露店整理事業で生まれた商業協同組合に 購入させて整理を進めて行った。しかし、それはあくまで根津山の 土地の一部であり、実際には根津山の土地の分譲によってマーケッ 

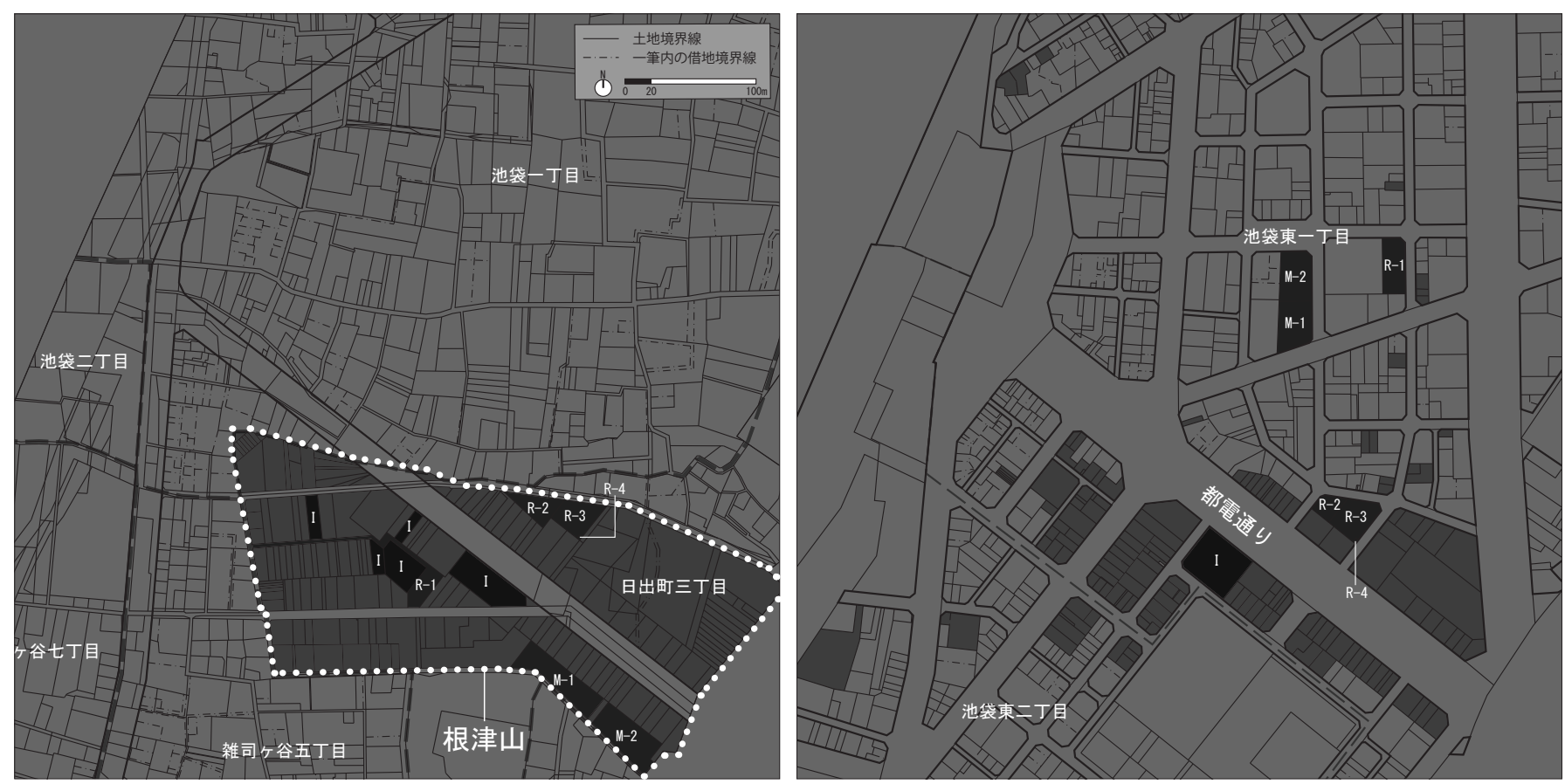

根津山の土地の換地。左が区画整理以前、右が区画整理以後。東京都市計画第 10-1 工区復興土地区画整理事業の換地確定図と換地 明細書（ともに東京都所蔵）より作成。

表 1 図 5 に関する換地情報。東京都市計画第 10-1 エ区復興土地区画整理事業換地明細書（東京都所蔵）より作成。

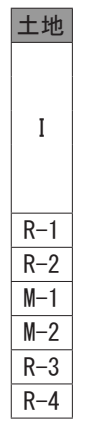

\begin{tabular}{|l|l|l|l|}
\hline 戦災復興土地区画整理事業 以前 & \multicolumn{3}{l|}{} \\
\hline 町丁名 & 地番 & 地目 & 地積 $\left(\mathrm{m}^{2}\right)$ \\
\hline 豊島区日出町 3 丁目 & $10-57$ & 宅地 & 198.35 \\
\hline 豊島区日出町 3 目 & $10-117$ & 宅地 & 198.35 \\
\hline 豊島区日出町 3 目 & $10-127$ & 宅地 & 198.35 \\
\hline 豊島区日出町 3 丁目 & $10-141$ & 宅地 & 780.17 \\
\hline 豊島区日出町 3 目 & $10-142$ & 宅地 & 1289.26 \\
\hline 豊島区日出町 3 丁目 & $10-19$ & 宅地 & 1157.16 \\
\hline 豊島区日出町 3 目 & $10-42$ & 宅地 & 494.65 \\
\hline 豊島区日出町 3 目 & $10-186$ & 宅地 & 1356.46 \\
\hline 豊島区日出町 3 目 & $10-187$ & 宅地 & 1367.18 \\
\hline 豊島区日出町 3 目 & $19-7$ & 宅地 & 9.79 \\
\hline 豊島区日出町 3 丁目 & $19-16$ & 宅地 & 786.91 \\
\hline
\end{tabular}

\begin{tabular}{|c|c|c|c|}
\hline 町丁名 & 地番 & 地目 & 地積 $\left(\mathrm{m}^{2}\right)$ \\
\hline 豊島区池袋東 1 丁目 & $95-8$ & 宅地 & 1650.58 \\
\hline 豊島区池袋東 1 丁目 & $21-2$ & 宅地 & 757. 39 \\
\hline 豊島区池袋東 1 丁目 & $24-4$ & 宅地 & 320.76 \\
\hline 豊島区池袋東 1 丁目 & $14-2$ & 宅地 & 938.61 \\
\hline 豊島区池袋東 1 丁目 & $14-1$ & 宅地 & 943.57 \\
\hline 豊島区池袋東 1 丁目 & $24-2$ & 宅地 & 9.92 \\
\hline 豊島区池袋東 1 丁目 & $24-3$ & 宅地 & 787.11 \\
\hline
\end{tabular}

\begin{tabular}{|l|}
\hline 減歩率 $(\%)$ \\
\hline 61.95 \\
\end{tabular}

卜営業者や露店商以外にも多くの新規地主が生まれていくことと なった。戦災復興土地区画整理第 10 - 1 工区の事業は都内でもきわ めて早期に進しだ。これ以降、池袋駅東口が急激に復興して行った 背景には、この根津山の分譲と新規地主の急増があったことは明ら かである。

\section{（3）戦災復興土地区画整理事業第 10-1 エ区の換地}

池袋駅東口を対象とした、東京都市計画第 10-1 地区復興土地区 画整理事業は 1946 年 4 月 25 日に都市計画決定、1948 年 9 月 2 日 に事業計画決定し、1960 年 10 月 31 日に換地処分されている ${ }^{24)}$ 。 戦災復興土地区画整理事業第 $10-1$ 工区は、換地処分が 1970 年前 後までかかった新宿や渋谷あるいは池袋西口と異なり、きわめて早 く事業が進んだことが特徵で、1953 年の火災保険特殊地図（図 7) をみると、寸でに街区の整備が完了していることがわかる。

東京都市計画第 10-1 地区復興土地区画整理事業では換地処分時 点で 978 筆の土地が存在したが、そのうち 187 筆が根津山の土地で あった。この根津山が分譲され、分譲されたことで土地所有権を持 たなかった森田組東ロマーケットの営業者の多くがフォーマルな権 利を持つようになっていった。図 5 は戦災復興土地区画整理前に根 津山であった土地の換地を示している。根津山であった土地を濃い
グレーで示し、戦災復興土地区画整理事業による換地の広がりを示 している。また、表 1 は図 5 の土地のうち、記号を振った 11 筆に ついてそれぞれの土地の換地情報を示している。図 5 からは根津山 であった土地が、ほぼ原位置にあたる都電通り沿いだけでなく、広 範囲に飛び換地されていることがわかる。

それでは、戦災復興土地区画整理事業によるマーケットの整理と 移転、露店整理事業事業に伴う営業者の集団移転の過程を区画整理 の換地とともに明らかにしていきたい。

\section{（4）森田組東ロマーケットの整理}

1949 年 2 月 17 日の『朝日新聞』によれば、森田組東ロマーケッ トは戦災復興土地区画整理事業の施行のため、1949 年 2 月 20 日 までに立ち退くよう都から指示されていた ${ }^{25)}$ 。立ち退きにあたり、 都は建物所有者である森田組と交涉を進め、営業者に対しては仮移 転場所として「三百数十世帯に対して三角小屋十軒分」を用意し、換 地として一坪三万円の土地を斡旋」するなどしたが、営業者はこれ に納得せず、1949 年 2 月 16 日に副知事と会見し立ち退き延期を申 し入れた。この時斡旋された「一坪三万円の土地」というのが、根 津山の土地だと推察される。

1949 年 3 月 2 日の『読売新聞』によれば、森田組東ロマーケッ 

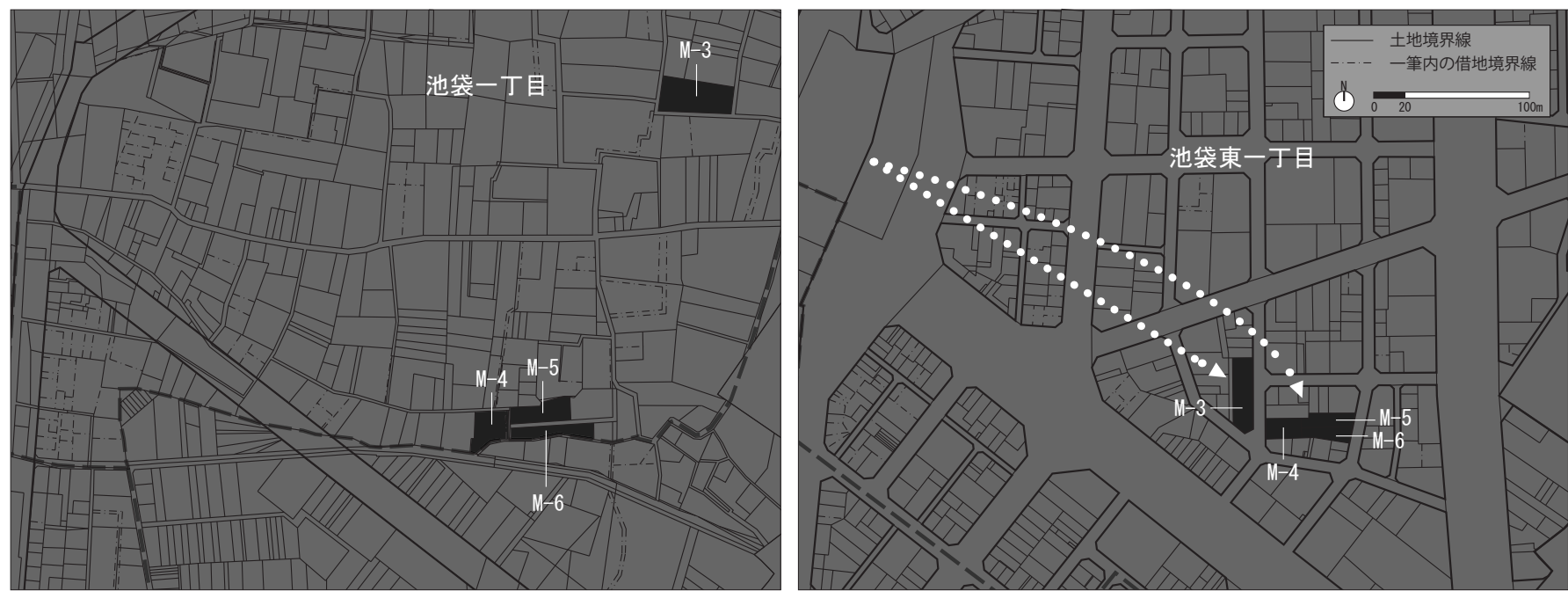

図 6 栄町通り・美久仁小路の土地の換地。左が区画整理以前、右が区画整理以後。東京都市計画第 10-1 工区復興土地区画整理事業の換地確 定図と換地明細書（ともに東京都所蔵）より作成。

表 2 図 6 に関する換地情報。東京都市計画第 10-1 エ区復興土地区画整理事業換地明細書（東京都所蔵）より作成。

\begin{tabular}{|c|c|c|c|c|}
\hline 土地 & 町丁名 & 地番 & 地目 & 地積 $\left(\mathrm{m}^{2}\right)$ \\
\hline$M-3$ & 豊島区池袋 1 丁目 & 689 & 宅地 & 961.98 \\
\hline$M-6$ & 豊島区池袋 1 丁目 & $807-1$ & 宅地 & 405.32 \\
\hline$M-5$ & 豊島区池袋 1 丁目 & $807-8$ & 宅地 & 426.88 \\
\hline$M-4$ & 豊島区池袋 1 丁目 & $809-1$ & 宅地 & 470.74 \\
\hline
\end{tabular}

\begin{tabular}{|l|l|l|l|}
\hline \multicolumn{3}{|l|}{ 戦災復興土地区画整理事業 以後 } \\
\hline 町丁名 & 地番 & 地目 & 地積 $\left(\mathrm{m}^{2}\right)$ \\
\hline 豊島区池袋東 1 丁目 & $13-1$ & 宅地 & 603.87 \\
\hline 豊島区池袋東 1 丁目 & $23-3$ & 宅地 & 276.13 \\
\hline 豊島区池袋東 1 丁目 & $23-4$ & 宅地 & 290.15 \\
\hline 豊島区池袋東 1 丁目 & $23-13$ & 宅地 & 301.22 \\
\hline
\end{tabular}

\begin{tabular}{|l|}
\hline 減歩率 (\%) \\
\hline 62.77 \\
\hline 68.13 \\
\hline 67.97 \\
\hline 63.99 \\
\hline
\end{tabular}

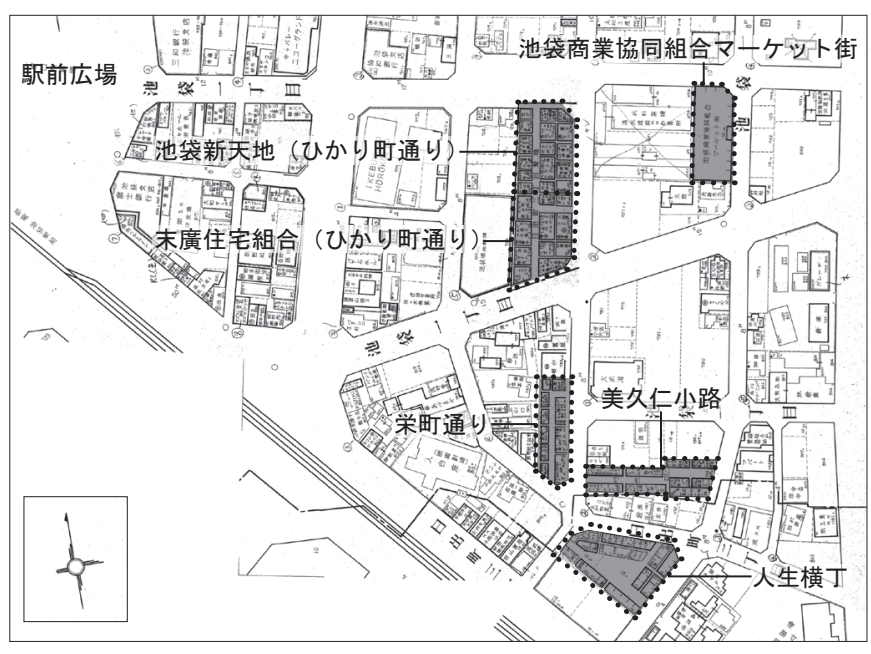

図 71953 年 10 月の池袋駅東口の火災保険特殊地図（都市整図社発 行）に筆者追記。

トは都に立ち退きを求められたとき 460 坪、20 棟に 298 戸の区画 があり、そのうち 11 戸には居住者がいたとし ${ }^{26)}$ 、他方で同日の『朝 日新聞』は 450 坪に 365 軒の店があったと伝えている ${ }^{27)}$ 。立ち退 きの延期を求めたが、受け入れられず 10 日ほど延期されたものの 1949 年 3 月 2 日に強制執行で取り壊しが決定したため、同月 1 日 に占有者は自主的にマーケットを取り壊し始めた。しかし、実際に はこの時も予定どおりには進まず、森田組東ロマーケットが本格的 に取り壊されたのは、1950〜 51 年にかけてであった ${ }^{28)}$

立ち退いた営業者の一部には、区画整理が進行中であった駅前広 場周辺に土地を借り、バラックを建設して営業を続けた者もいた。 松平誠の『ヤミ市 東京池袋』には、こうした営業者二名の証言が 収録されているので紹介したい。

ひとり目の志田恒平（仮名）は、戦中はパイロットであったが、
終戦から 2 年後に西口の復興マーケットで八百屋を開いた後、西口 の復興マーケットと森田組東ロマーケットでパチンコ屋を営んだ人 物である ${ }^{29)}$ 。森田組東口マーケットが、区画整理で取り壊されると、 西口の復興マーケットの店を売って、「森田組東ロマーケットのす ぐ裏で…一時的なマーケットみたいなもんで…一年中華料理屋を やった」という。このマーケットのような商店が並んだバラックは、 4 軒続いた長屋で、志田の店はその角に位置していたという。志田 はその長屋の裏に空地があったため、6 畳ほどの 2 階建ての住まい を建て、そこに住んでいた。1 年ほどで、この店と住宅も取り壊す ことになり、志田は 1948 年ごろに購入していた根津山の土地へ移 転して行くことになった。

ふたり目の加賀谷勇（仮名）は、1946 年ごろから森田組東口マー ケットでそば屋を営んだ人物である ${ }^{30)}$ 。森田組東ロマーケットの 整理が始まると、都から立ち退き料をもらって立ち退いたという。 加賀谷はそのとき、三越の所有地の北側にあった池袋会館という戦 前からの料理店の空いている土地を借りて移転した。この時期に は、新設のマーケットは認められていなかったため、加賀谷を含め、 まとまって移転した 7 軒は車輪がついた屋台風の小屋をつくり、移 動可能ということで都から許可を得た。実際には動かすための車輪 ではなく、移動式であるという意味を示すための車輪であった。そ の後、同地に掘建小屋でマーケットを建設し、吞み屋を始めたがす ぐに立ち退くこととなり、区画整理後の池袋会館横の空地に移った という。そこでも 7 軒でマーケットを建設して飲み屋を続け、1954 年ごろまで営業した。その後、加賀谷は地主から同地を買い取り、 それをすぐに三越に転売した。その金を資金とし人生横丁の空いた 区画を購入し、人世横丁へ移転したという。人生横丁は露店整理事 業によってできた新設のマーケットである。

このように森田組東ロマーケットの整理が始まってから完了する 
1954 年ごろまでは、志田、加賀谷や加賀谷とともに移転した 6 軒 の営業者のように駅前広場周辺の土地に、バラックを建設し営業を 続けた人々がいた。駅前広場が竣工し周辺の土地でも本建築の建設 が始まると、そうした人々ももう一度立ち退きを求められ、さらに 移転して行くことになった。

駅前から立ち退いた営業者たちは、その後、個人で代替地を見つ けて移転するものもいれば、まとまって土地を購入し新たにマー ケットを建設するものもいた。池袋駅東口に戦後誕生したマーケッ トの営業者が集団で移転したマーケットには、ひかり町通り、栄町 通り、美久仁小路があった ${ }^{311}$ 。このうちひかり町通りは根津山の 土地の換地に建設されている。また、栄町通り、美久仁小路を建設 することになる営業者たちも 1947 年の航空写真では焼け跡や、畑 になっていた土地を購入しマーケットを建設している。こうした土 地は、戦前は空地であるか、あるいは住宅が立ち並んでいた。

ひかり町通り、栄町通り、美久仁小路といった呼称は、マーケッ トが誕生した当時のものではない可能性が高いが、ここでは便宜的 にこれらのマーケットを通称で呼ぶこととする。それではこうした 区画整理後に誕生したマーケットの誕生の経緯を考えていこう。

\section{（5）栄町通りと美久仁小路の誕生}

まず、栄町通りについて見ていこう。図 6 は、戦災復興土地区画 整理事業による栄町通りと美久仁小路の土地の換地を示している。 また、表 2 は図 6 のうち、記号を振った 4 筆の土地の換地情報を示 している。栄町通りは図 6 の M-3 の土地 [前: 池袋 1 丁目 689 /後: 池袋東一町目 13-1] を集団で購入し、建設されたマーケットであ る。土地 M-3 は、区画整理前は $961.98 \mathrm{~m}^{2}$ の土地であったが、区画 整理によって減歩され $603.87 \mathrm{~m}^{2}$ にっている。土地 M-3 は 1938 年 の火災保険特殊地図（図 1）では、空地となっており、1947 年の航 空写真（写真 1) でも建物が建っていない。土地 M-3 の旧土地台帳 は散逸しており、戦前戦後の土地所有者について知ることはできな いが、法務局で現在公開されている土地 M-3 の登記情報によれば、 土地 M-3 は 1951 年 11 月 30 日に 25 名によって買収されている。

換地後の M-3 は南北に長い敷地で、東と南で接道している。マー ケットがいつ建設されたかは不明であるが、1953 年 1 月に調査さ

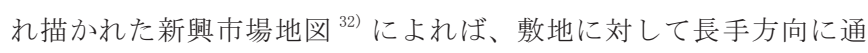
路が取られ、この通路と東側の道路に面して 34 軒の店が並んでい る。このうち 17 軒が酒場となっている。栄町通りは現在も飲屋街 として賑わっている。

次に美久仁小路について見ていこう。美久仁小路は図 6 の区画 整理後の土地 M-4・M-5・M-6 に建設されたマーケットである。土地 M-4・M-5・M-6 はそれぞれ区画整理前後の地番でいえば、M-4［前： 池袋 1 丁目 809-1/後: 池袋東一町目 23-13] - M-5 [前：池袋 1 丁 目 807-8/後: 池袋東一町目 23-4] - M-6 [前：池袋 1 丁目 807-1 / 後: 池袋東一町目 23-3] である。1938 年の火災保険特殊地図（図 1）を見ると、これらの土地の一部には木造長屋の住宅が建ってい るが、大半は空地であり、戦後の 1947 年の航空写真（写真 1) で は建物は建設されていない。土地 M-4・M-5・M-6 の旧土地台帳も法 務局豊島出張所には保管されておらず、戦前から戦後すぐの所有関 係を明らかにできない。しかし、土地 M-3 同様に法務局で現在公開 されている登記情報から土地 M-4［池袋東一町目 23-13）は 1951 年 5 月 29 日に 18 名によって購入されたこと、土地 M-5 [池袋東一町
目 23-4）と土地 M-6 [池袋東一町目 23-3］は 1949 年 4 月 3 日にそ れぞれ同じ 17 名によって購入されたことがわかる。M-5 と M-6 は 登記されている所有者が一致しており、購入日も同日であることか らもまとまった 17 人の営業者がマーケットを建設するために購入 したと考えられる。M-5 と M-6 の土地取得は、森田組東ロマーケッ トの整理が始まった直後である。区画整理で土地 M-4 は $470.74 \mathrm{~m}^{2}$ から $301.22 \mathrm{~m}^{2}$ 、、土地 M-5 は $426.88 \mathrm{~m}^{2}$ から $290.15 \mathrm{~m}^{2}$ 、 、土地 $\mathrm{M}-6$ は405. $32 \mathrm{~m}^{2}$ から $276.13 \mathrm{~m}^{2}$ へ減歩されている。

この土地 M-5 と土地 M-6 に続いて、土地 M-4 が 18 人によって購 入され、土地 M-5、土地 M-6 と連続してマーケットが建設された。 土地 M-4 を購入した 18 人のうち、 2 名は土地 M-5 の購入者と一致 寸るがその他の 16 人は新たに参加した営業者であると考えられ、 美久仁小路の土地は計 33 名によって土地が取得されマーケットが 建設された。マーケット自体がいつ建設されたかは不明であるが、 1953 年 1 月に調査された新興市場地図では、美久仁小路に 39 区画 の店舗と住宅が確認できる。このうち 23 軒が酒場になっている。 美久仁小路も飲屋街として現在も賑わっている。

こうして戦後に駅前に建設されたマーケットの営業者の一部は、 駅から 300 メートルほど離れてしまったものの、区画整理用地内に 栄町通り（34 軒）と美久仁小路（39 軒）を建設し、営業を続けた。 図6でいえば、彼らは点線のように移動したのである。

\section{（6）根津山の分譲とひかり町通りの誕生}

これから見ていくひかり町通りのマーケットは、根津山の土地の 換地に誕生したものである。また、池袋駅周辺における露店整理事 業ではふたつのマーケットが誕生しているが、その土地もかつて根 津山であった土地であった。

まず、ひかり町通りの形成を見ていこう。ひかり町通りは、図 5 の土地 M-1 と土地 M- 2 に建設されたマーケットである。ともに区画 整理前は根津山の南東端に位置した土地で、土地 $M-1$ [前：日出町 3丁目 10-187/後：池袋東一町目 14-1] は1951年 5 月 31 日に有 限責任末廣住宅組合によって買収されており、一方の土地 M-2 [前： 日出町 3 丁目 10-186/後: 池袋東一町目 14-2］は 1950 年 8 月 22 日に池袋新天地株式会社に買収されている。

1953 年 10 月作図の火災保険特殊地図（図 7）をみると、土地 M-1・M-2 を一帯の敷地として南北に通路を通し、その通路と東側 の道路に向かって店を並べているが、土地 M-1 のマーケットは北側 で東の道路と接続する動線を持っており、その部分では店をこの 動線に向かって並べることで、土地 $\mathrm{M}-1$ だけでまとまりを持つ配置 にもなっている。「ひかり町通り」とは土地 M-1 と土地 M-2 に建設 されたマーケットをまとめて後に呼ばれるようになった呼称で、実 際にはふたつの主体によって開発されたマーケットであった。1953 年 10 月作図の火災保険特殊地図（図 7) からは、土地 M-1 と土地 M-2 それぞれに 33 軒の店が並んでいることが確認できる。

土地 M-2 を買収した有限責任末廣住宅組合は、旧土地台帳から所 在地が「豊島区池袋 1 丁目 824」であることがわかる。この住所は、 池袋駅南東側に戦後にできた東ロマーケットの住所に一致する。東 ロマーケットを開発した主体が、新たにマーケットを開発すること を目論み 1950 年に根津山の土地 M-2 を買収し、換地にマーケット を建設した可能性があるが、それを明らかにできる資料は管見の限 りない。 
その一方で、土地 M-1 のマーケットは、池袋新天地株式会社が土 地 M-1 ヘマーケットを開発し、森田組東ロマーケットを含めた戦後 に駅前に建設されたマーケットの営業者の一部が店子として入居 している。さらに、土地 M-1 [前：日出町 3 丁目 10-187/後：池 袋東一町目 14-1]は、1951 年 6 月 28 日に 31 名に売却されており、 入居した営業者へ分譲されている。31名のうち 29 名の住所は土 地 M-1 である「日出町 3 丁目 10」となっているものの、2 名は「池 袋 1-762」となっている。「池袋 1-762」とは森田組東ロマーケット が建っていた土地の一部であり、少なくともこの 2 名は森田組東口 マーケットに居住していた営業者であった。

これまで焼け跡の未利用地を集団で購入して建設されたマーケッ 卜や、有限責任末廣住宅組合や池袋新天地株式会社といった法人が 根津山の土地を購入しマーケットを建設した過程を見てきたが、池 袋駅東口に戦後建設されたマーケットの営業者の移転先は、こうし た新設のマーケットだけではなかった。

たとえば、先に紹介した志田恒平は、こうした新設のマーケット に入居していない。1948 年ごろに、根津山の土地が売りに出てい ることを看板で知り、西口の復興マーケットと森田組東ロマーケッ トのパチンコ屋で稼いだ金を資金に、さらに借金をして 65 坪の土 地を購入している。この土地が戦災復興土地区画整理事業によって 40 坪に減歩されたが、志田はそこへ連れ込み旅館を建設し経営し た。

この当時、森田組東ロマーケットの営業者のなかには、志田恒平 のように根津山の土地の分譫を知り、土地を購入した人々が他にも いたはずだ。また、他のマーケットの営業者や、マーケット営業者 以外でも土地を取得し地主になっていった人々が池袋駅東口には多 く存在した。そして、根津山の土地を購入した主体にはそうした個 人だけでなく、伊勢丹のような百貨店も含まれる。伊勢丹は、根津 山の土地を計 5 筆、 $2664.48 \mathrm{~m}^{2}$ を購入している。そして、これらの 土地は区画整理によって合筆され、1650.58 $\mathrm{m}^{2}$ の土地となった(図 5 ・ 表 1)。伊勢丹はその土地に池袋店を建設する計画で、当時の新聞 にも紹介されている ${ }^{33)}$ 。伊勢丹は用地取得をしただけで、池袋に は出店しなかった。しかし、この当時、急速に成長する西のターミ ナル、とくに東急が地歩を固める渋谷を除いた新宿と池袋は、どの 百貨店にとっても進出を狙う重要なエリアであったことは確かだ。 このように戦後の根津山の分譲は、個人から大企業までさまざまな 地主を生み出し、池袋駅東口の戦災復興にきわめて大きな影響を与 えた。

\section{（7）露店整理事業による人生横丁・池袋商業協同組合マーケット 街の建設}

先に見た通り、池袋駅周辺には図 4 のように露店が分布していた。 『読売新聞』によれば、池袋の露店整理事業では、このうち東口の 68 軒と、西口の 65 軒の露店が池袋商業協同組合（理事長小川竹松 氏）を結成し、豊島区役所土木課との交渉を行った。1951 年 7 月 2 日に区有地の払い下げが決定し、西武鉄道所有地と個人名義の土地 も「池袋発展のためなら…上時価より安い值段で売買が行われる ことが当事者間で決定し、「恒久的な商店街として更生することに なった」という ${ }^{34)}$ 。土地取得の交渉には 1 年を要している。池袋 の露店がまとまってマーケットを建設することとなった区有地、西 武鉄道所有地、個人名義の土地はすべてかつての根津山であった土
地である。

具体的には図 5 に示した土地のうち、土地 R-1 が戦後に西武鉄 道所有地となった土地「日出町 3 丁目 10-19」、土地 R-2 が根津山 のなかでも珍しく終戦前の 1942 年 10 月 7 日に根津育英会から個人 一分譲されていた土地「日出町 3 丁目 10-42」、土地 R-3 と土地 R-4 が豊島区の土地として御野立所公園となっていた土地「日出町 3 丁 目 19-16」である。旧土地台帳から土地 R-3 と土地 R-4 もかつては 根津山であったことがわかる。

池袋商業協同組合は、商工中金から融資を受け、これらの土地を 購入しマーケットを建設することになった。区画整理でこれらの土 地は、土地 $\mathrm{R}-1$ とそれ以外の土地 $\mathrm{R}-2 \cdot \mathrm{R}-3 \cdot \mathrm{R}-4$ とに分かれて換地 されている。そして土地 $\mathrm{R}-1$ には池袋商業協同組合マーケット街が、 土地 $\mathrm{R}-2 \cdot \mathrm{R}-3 \cdot \mathrm{R}-4$ には人生座の近くということで人生横丁という 名のマーケットが建設された。

池袋周辺の露店の立ち退きを予定通り進めるよう、1951 年 11 月 中旬に池袋署は池袋駅東西両口の露店代表者を呼んで 11 月末での 立ち退きを通告したが ${ }^{35)}$ 、結局露店業者は立ち退かず、1952 年 11 月時点でも露店は東口の裏通りで営業を続けていた ${ }^{36)}$ 。この時に はすでに 2 カ所のマーケットは建設されていたが、1953 年 1 月に 調查された新興市場地図では人生横丁の店舗はすべて空き店舗と表 記されており、店は入っていなかったようである。これが 1953 年 10 月作図の火災保険特殊地図（図 7) になると、人生横丁の半数ほ どの区画には店名が入っている。つまり人生横丁の建物は 1952 年 末には完成していたものの、露天商は駅前の立地を手放すことがで きず露店のまま営業を続け、1953 年半ばになって徐々に入居して いったものと考えられる。

また、人生横丁は発足当初から店の入れ替わりが起きていたよう で、先に紹介した加賀谷勇は駅前の池袋会館横のバラック店舗が立 ち退きとなると、1954 年に人生横丁の 1 区画の権利を 35 万で買っ て移転している。人生横丁と池袋商業協同組合マーケット街は、土 地も建物も池袋商業協同組合所有となり、組合員がそれを使用し、 月々商工中金への借金を返すことになっていた。

人生横丁は 2008 年 7 月末で営業を終了し、南側の土地を含めた 街区全体で再開発された。現在は同地に超高層ビルが建っている。 人生横丁は 2007 年 3 月時点でも土地・建物は組合によって所有さ れており、権利が個人に分かれていなかったことが、再開発を容易 に進める要因となった。

\section{（８）戦災復興土地区画整理事業の市街化計画図}

こうして 1953 年には、区画整理が進んだ池袋駅東口に新設のマー ケットが複数誕生した（図 7)。中島伸は東京都が作成した戦災復 興土地区画整理事業の市街化計画図について博士論文「戦災復興土 地区画整理事業による街区設計と空間形成の実態に関する研究 東 京都戦災復興土地区画整理事業地区を事例として ${ }^{37)}$ で分析を行い、 戦災復興土地区画整理事業後の市街地の計画が緻密に行われていた ことを明らかにしている。池袋駅周辺を対象とした戦災復興土地区 画整理事業第 10 工区の市街化計画図は、1948 年 9 月 2 日に作成さ れている ${ }^{38)}$ 。これによれば、これまで見てきた新設マーケットが 建設された場所は、市街化計画図の土地利用上は特殊飲食業、興行 場・遊技場に指定されている。東京都はこの辺りに都市計画的な意 図を持って飲食店街をつくろうとしていた。新設マーケットは、こ 
うした都市計画的な意図が反映され、まとまりを持って換地されて いた。

\section{5. おわりに}

以上見てきたように、池袋駅東口周辺の戦災復興を森田組東口 マーケットの形成と整理、そして戦災復興土地区画整理事業による 換地と、区画整理後に建設された複数のマーケットの形成過程を明 らかにした。

対象地区の戦災復興土地区画整理事業は、雑木林として戦後も残っ ていた根津山が分譲されたことで、交通疎開空地であった土地に建 設された森田組東ロマーケットの整理がスムーズに進んだ。また、 市街地の再建が進んでいたかったため、マーケット営業者が取得し や寸い焼け跡の土地が多く存在したこともマーケットの整理が早期 に進んだ背景にあった。こうしたことが、他の新宿・渋谷といった 戦後に副都心と呼ばれるようになるエリアの戦災復興土地区画整理 事業と比較して、池袋駅東口が早期に換地処分される要因となっ た。これは東京の戦災復興土地区画整理事業の中でも特異な事例と 言える。

また、根津山の土地の分譲はマーケットの整理をスムーズにした と同時に、多数の新規地主を生んだ。こうした新規地主には、闇市 を起源とするマーケットや露店の営業者だけでなく、伊勢丹などの 大資本も含まれていた。池袋が戦後に副都心几と成長し、繁華街を 形成していく基盤にこの根津山の分譲があった。

\section{注}

1) 東京百年史編集委員会『東京百年史 第六巻 東京の新生と発展』東京都、 1972 年、 79 頁。

2) 石榑督和・青井哲人「闇市の形成と土地所有からみる新宿東口駅前街区の 戦後復興過程 新宿駅近傍における都市組織の動態をめぐってその $1 」$ 『日本建築学会計画系論文集』第 78 巻第 694 号、2627-2636 頁。

3) 星野朗・松平誠「池袋『やみ市』の実態一第 2 次世界大戦後の戦災復興マー ケット一」『応用社会学研究』 25 号、1984 年、8 8 - 153 頁。また、これを もとにした松平誠『ヤミ市 東京池袋』ドメス出版、1985 年。

4) 初田香成『都市の戦後 雑踏のなかの都市計画と建築』東京大学出版会、 2011 年。

5)村上しほり「三宮東地区『三宮国際マーケット』の形成と変容過程につい て 戦後神戸における中ミ市と市街地形成に関する史的研究」『日本建築 学会計画系論文集』第 78 巻第 693 号、2433-2438 頁。

6) 株式会社三越本社編『株式会社三越 100 年の記録』株式会社三越、2005 年、 121 頁。

7)豊島区池袋 1 丁目、同 2 丁目、雑司ヶ谷町 5 丁目の 5300 坪。東京都『東 京都戦災誌』明元社、2005 年、186-188 頁。

8) 東京都前掲『東京都戦災誌』182 頁。

9) 星野朗・松平誠前掲「池袋『やみ市』の実態」の 4 章として揭載されて いるが、独立した論文として成立している(『応用社会学研究』119-142 頁)。 10)『応用社会学研究』 25 号、1984 年、83-119 頁。

11) 松平誠は各所で森田組東ロマーケットを都内最初の連鎖市場（マーケッ 卜）であると強く主張しているが、マーケットと呼ばれる長屋状の建物 は戦前から存在し、また戦後でいえば新宿東口の新宿マーケットは 1945 年中には木造長屋形式の店舗になっている。また、松平が『ヤミ市東 京池袋』(ドメス出版、1985 年) で不都合な部分を省略をしながら引用し ている 1946 年 1 月 19 日の『朝日新聞』を見ると、松平がマーケットを指 寸言葉であるとした「連鎖市場」「連鎖店」は店が連なる建物形状を示 した言葉ではなく、「チェーンストア」を意味し、経営形態を示している
言葉であることがわかる。

12)「池袋に連鎖市場の店開き」『朝日新聞』1946 年 2 月 13 日朝刊、 2 頁。

13) 星野朗・松平誠前掲「池袋『や夕市』の実態」122 頁、128頁。

14) 松平誠前掲『ヤミ市 東京池袋』33-34 頁。

15) 東京の疎開空地が戦前の地権者や占有者へ変換されていったことは、越 沢明が『復興計画』(中央公論新社、2005 年) で指摘している。また、石 榑督和・青井哲人前掲「闇市の形成と土地所有からみる新宿東口駅前街 区の戦後復興過程」では、新宿駅前の交通疎開空地として都有地となっ ていた土地が、1947 年 9 月までに戦前の所有者に売却するか、1948 年に 払い下げするかによって民有地一と変わっていったことを明らかにして いる。1946〜 47 年の主要新聞では、疎開空地の戦前の地権者に名乗り出 るよう呼びかける記事が掲載されている。

16) 旧土地台帳が散逸しているため、1947 年前後の森田組東ロマーケットの 土地の所有者は不明だが、1960 年 10 月 31 日時点（同地の区画整理の換 地処分日）では同地に都有地がないことが東京都所蔵の戦災復興土地区 画整理事業 10-1 工区の換地明細書からわかる。つまり、森田組東口マー ケットが占有した土地で、交通疎開空地として都に買収され、戦後になっ ても戦前の地権者へ返還されることなく、都有地のまま区画整理を迎え た土地はないということである。

17)「元森田組幹部検挙」『朝日新聞』1948 年 7 月 30 日朝刊 2 面。

18) 由井常彦編『セゾンの歴史 上巻』リブロポート、1991 年、47-48 頁。

19)同書、43 頁。

20)同書、43 頁。

21) 建設省編『戦災復興誌 第拾卷』都市計画協会、1961 年、83 頁。

22) 東京都建設局区画整理部計画課『甤った東京東京都戦災復興土地区画 整理事業誌』1987 年、226 頁。

23) 由井前掲『セゾンの歷史 上卷』 43 頁。

24) 東京都建設局区画整理部計画課前掲『延った東京 東京都戦災復興土地 区画整理事業誌』106 頁。

25)「池袋マーケット立退き延期を申入れ」『朝日新聞』1949 年 2 月 17 日朝 刊 3 面。

26)「池袋東ロマーケット取りこわし」『読売新聞』1949 年 3 月 2 日朝刊 2 面。

27)「池袋東ロマーケット取り壊し始まる」『朝日新聞』1949 年 3 月 2 日朝刊 2 面。

28) 松平誠前掲『ヤミ市 東京池袋』131 頁。

29) 志田恒平 (仮名) の聞き取りについては、松平誠前掲『ヤミ市東京池袋』 80 - 109 頁。

30 ) 加賀谷勇（仮名）の聞き取りの内容は、松平誠同書 110 - 130 頁。

31 ) 橋本健二『居酒屋ほろ酔い考現学』毎日新聞社、2008 年、100 頁。

32 ) 新興市場地図とは、都市整図社が火災保陘会社の要請により作成したと 推察される火㷋保険特殊地図の一種で、1953 年 1 月から 1962 年 12 月の 間に作成された地図である。縮尺は $1 / 600 \sim 1 / 300$ で、東京都 23 区を網 羅し、全 138 枚、281の「新興市場」が描かれている。詳しくは、石榑督 和・初田香成『新興市場地図』にみる戦後東京のマーケットの建築的分析」 (『日本建築学会計画系論文集』第 79 巻第 705 号、2589-2597 頁) を参照。

33)「デパート新地図 大阪方の攻勢 狙う東京駅、銀座、新宿、池袋」『読 売新聞』1952 年 11 月 23 日夕刊 3 面。

34)「生まれかわる露店商 池袋に新商店街 土地・資金・漸く緾まる」『読 売新聞』1951 年 7 月 14 日朝刊 4 面。

35)「池袋露店に立退要求 月末までの期限付きで」『朝日新聞』1951 年 11 月 16 日朝刊 3 面。

36)「池袋東口の露店解消」『朝日新聞』1952 年 11 月 12 日朝刊 8 面。

37) 中島伸「戦災復興土地区画整理事業による街区設計と空間形成の実態に 関する研究 東京都戦災復興土地区画整理事業地区を事例として」東京大 学博士論文、2013 年、280-287 頁。

38 ) 戦災復興土地区画整理事業第 10 工区の市街化計画図は中島伸「戦災復興 土地区画整理事業による街区設計と空間形成の実態に関する研究 東京都 戦災復興土地区画整理事業地区を事例として」（東京大学博士論文、2013 年）の巻末資料所収。 


\title{
THE WAR-DAMAGE-RECOVERY PROCESS OF THE IKEBUKURO STATION EAST GATE, WITH RESPECT TO THE FORMATION OF THE MORITA-GUMI EAST GATE MARKET AND THE WAR-DAMAGE-RECOVERY LAND READJUSTMENT PROGRAMS
}

\section{Masakazu ISHIGURE*}

\author{
* Assist. Prof., Dept. of Architecture, Faculty of Engineering, Tokyo Univ. of Science, Dr. Eng.
}

\begin{abstract}
This study takes as its subject the east gate of Ikebukuro station. Having verified the prewar organization of the city and plans for the square in front of the station, the study reveals the scope of the transport evacuation spaces, the state of war damage, the formation of postwar markets, street stand organization programs, and the reorganization of markets following war-damage-recovery land readjustment programs, and accordingly the subsequent process of new market construction. Particular attention is paid to the fact that Nezuyama, a grove of mixed trees that had not been developed since before the war, was located adjacent to Ikebukuro station. The war-damage-recovery land readjustment program for the Ikebukuro station east gate progressed most rapidly even within the city; one of the background factors here was the existence of Nezuyama.
\end{abstract}

This study revealed the following four points:

1. The land upon which the Morita-gumi East Gate Market was built was revealed to have been a transport evacuation space from which buildings had been removed during the war. The Morita-gumi constructed the market, despite not having owned the land. This state of affairs was picked up on by the newspapers. This was backgrounded by the evacuation space having become either city-owned or city-managed land after having been either purchased or leased by the Tokyo Metropolitan Area from during the war until around 1947. At the time the Morita-gumi constructed the market, the city had held the rights to the land, and thus the Morita-gumi had obtained the cooperation of the city in building the market.

2. It was revealed that many new landowners appeared as Nezuyama was divided into lots for sale in the process of the war-damage-recovery land readjustment program. There was a rapid increase in landowners possessing land near the station owing to land having been widely divided and sold, not only among the merchants in the markets organized by the war-damage-recovery land readjustment program.

3. It was revealed that the above subdivision of Nezuyama for sale resulted in the construction of multiple new markets. Hikarimachi-dori and two markets created following the street stand organization programs were constructed on the replotted land that used to be Nezuyama.

4. It was revealed that two new markets were constructed following the purchase of land that was left empty as a burned-out field after the war. These markets were Sakaemachi-dori and Mikuni-koji. 